\title{
Production and Export Potential of the Grain Sub-Complex of the EAEU Countries
}

\author{
Rafail R. Mukhametzyanov $\left.{ }^{1 *[O R C I D} 0000-0002-1239-5201\right]$, \\ Anastasiya S. Zaretskaya 2[ORCID 0000-0002-8438-7729], \\ Gulnara K. Dzhancharova 1[ORCID 0000-0002-1098-7430], \\ Nikolay G. Platonovskiy 1[ORCID 0000-0002-9189-8340], \\ Nataliya V. Arzamastseva 1[ORCID 0000-0002-3775-0505]
}

\footnotetext{
${ }^{1}$ Russian State Agrarian University - Moscow Timiryazev Agricultural Academy, Moscow, Russia

${ }^{2}$ Yaroslav-the-Wise Novgorod State University, Veliky Novgorod, Russia mrafailr@yandex.ru
}

\begin{abstract}
The grain sub-complex is the most important structural element of the agrarian sector in many countries of the world. The production of grain and its processing create the basis for satisfying the internal needs of the country's population for those food products in which this type of product is used to a certain extent. It does not concern only bread and bakery products, pasta, cereals or confectionery. Grain as a raw material for the production of animal feed is indirectly involved in the production of eggs, milk, meat, and food products which use them. Thus, the level of development of the grain sub-complex largely determines the degree of ensuring the full-fledged food independence of the country. Besides, due to this dependence, the grain market conditions greatly affect many other national food markets; the negative grain market situation can have profound consequences for political stability in the country. Consequently, the research on the production potential of the grain sub-complex of Russia and other states located in the post-Soviet space has acquired the paramount importance. After the collapse of the USSR, the grain production in the emerged fifteen independent states was developing in different ways. Some of the countries, including Russia, managed to significantly increase the production and export potential of the national grain sub-complex. The given research used statistics data of the United Nations Food and Agriculture Organization for the period of 1992-2019 to analyze the physical quantity of grain production in Russia and neighboring countries. The authors also consider the change trends in the parameters of grain export from the states, which in 2019 were the main exporters of grain from this part of the world. The particular attention is paid to the changes in the gross grain harvests structure in the EAEU member states, as well as to the production of grain per capita in the states that belong to this integration group.
\end{abstract}

Keywords: cereals, grain production, gross harvest, export, economic integration, the Eurasian Economic Union $(E A E U)$

\section{INTRODUCTION}

The grain sub-complex as a whole and its production components cultivating specific cereal and pseudo-cereal crops is an important element of the economy in many countries. As some researchers note, growing grain is a pivotal basis not only for crop production, but for all agricultural production. This industry has multilateral ties with other areas of the agricultural sector and a number of industries, in particular flour and cereals, food and feed industries [1].

The range of cultivated plants used for grain production is wide enough. However, some of them occupy the leading positions in the corresponding ranking of the most significant cereals. In 2019, the whole world produced 2.979 billion tons of grain. Of these, corn accounted for $38.55 \%$ of the global gross harvest, wheat $-25.7 \%$, rice $-25.36 \%$, barley - 
$5.33 \%$, sorghum $-1.94 \%$. Thus, the first three crops together gave $89.62 \%$, and the first five $-96.9 \%$ of all grain obtained on Earth.

In different countries, depending on certain factors, including natural and climatic, the importance of specific cereal crops in production volumes and their place varies. In China, in 2019, corn was in the first position with volumes of 261.0 million tons; rice was in the second position (211.4 million tons), wheat occupied the third place (133.6 million tons). In India, the corresponding positions were occupied by rice (177.6 million tons), wheat (103.6 million tons), corn (27.7 million tons). In the USA, corn (347.0 million tons), wheat (52.3 million tons), sorghum (8.67 million tons) took the firstthird places, respectively.

The importance of the grain sub-complex is determined not only from the point of view of ensuring food independence and security of the countries of the world, but also in regards to their political stability [2]. Food security is one of the main elements of the economic security of the state, the importance of which is predetermined by the role of food security in achieving stability in society, both in the social and economic spheres [3]. Some countries, particularly in the North Africa and in the Middle East, do not fully saturate the national grain market through their own production, being highly dependent on the grain import. Amid the rise of the world food prices, some of these states encountered riots and uprisings, referred to as the "Arab Spring" in the research literature. In some countries, there were revolutions, a change of power; in Libya and Syria, large-scale hostilities started and are still going on. For this reason, those countries that are powerful geopolitical players need to rise the national grain economy to the level of at least self-sufficiency of their own needs. This fully applies to Russia.

During its existence, the USSR paid great attention to the development of the grain subcomplex; however, the implemented measures were not always effective. For example, the 1950s campaign for the development of "virgin and fallow lands" in the south of Western Siberia and in the north of Kazakhstan, gave a positive short-term result of an increase in gross grain harvests. However, nine years after its start, the positive achievements from the implemented measures began to be leveled off by negative effects, including those related to the impact on the environment. Land cultivation methods that did not correspond to the natural and climatic conditions of these regions gradually contributed to the degradation of the land, the manifestation of the so-called "black storms". The thin fertile soil layer of these territories was quickly depleted. Taken together, all this led to a decrease in yields and gross grain harvests. In the arid steppe, the rain growing was carried out mainly in an extensive way, it did not solve the problem of grain shortages both for the development of the grain sub-complex and for other sectors of the USSR national economy, in particular animal husbandry. As a result, in the 1970-1980s, the USSR became a stable net importer of grain.

The collapse of the USSR caused the destruction of a single economic space, which had been uniting 15 republics for many decades. The result was a reduction or degeneration of many interregional relations and connections. In the early 1990s, the emerging independent states began to independently carry out reforms, including those in the agroindustrial complex. During the period covered by the given research, some countries encountered the decrease in agricultural production, destruction of the potential of large-scale production, despecialization of the industry in some naturalagricultural zones, and a reduction in the flow of a number of food products both within some states and between them [4]. These tendencies, to one degree or another, have also affected the grain subcomplex of Russia and neighboring countries.

The Eurasian Economic Union (EAEU), which at the time of the study, consists of five states Armenia, Belarus, Kazakhstan, Kyrgyzstan and Russia - is a relatively "young" integration group of countries located in the post-Soviet space. Its establishment was preceded by a long and thorny path of attempts to enhance interaction and complementarity of the national economies of the states formed after the collapse of the USSR [5].

Thus, the issues of the relationship between the process of grain production and related products, both from the point of view of meeting the country's internal needs and the development of the export potential of this industry, represent a rather deep complex of research problems. In this regard, the research aim is to identify the main trends that developed during 1992-2019 in regards to changes in production volumes and development of the export potential of the grain sub-complex of the EAEU countries in general and Russia in particular.

\section{MATERIALS AND METHODS}

The research aim is to identify those changes in the development of the production and export 
potential of the grain sub-complex of the EAEU countries that took place in 1992-2019, primarily in Russia. To achieve this aim, the following objectives were identified:

- to analyze the dynamics of gross grain harvest in Russia and neighboring countries in the period of 1992-2019;

- to identify changes in grain production by type and per capita in the EAEU states;

- to assess the importance of Russia in grain export.

The main information base for research is the statistical data of FAO (Food and Agriculture Organization of the United Nations). The data analysis was carried out according to the following methodology: within the general period of dynamics 1992-2019, three sub-periods were singled out 1992-2000, 2001-2010, and 2011-2019. Average annual values were calculated for each of them, and the situation in 2019 was compared with 1992. In order to compare the changes in gross harvests and grain export parameters during the period of the USSR existence and after its collapse (for comparison with the global production and export of this type of product), we considered it necessary to introduce an aggregated group "USSR"; its indicators for the period of 1992-2019 is a summation of the corresponding data for all fifteen independent countries that were at one time the USSR republics. Likewise, but on the basis of a smaller number of countries, the EAEU group has been formed [6].

\section{RESULTS}

This part presents the ample results of research analysis of grain production and the identification of the export potential for this type of product in the considered group of countries, including Russia. Before studying the situation in the EAEU, let us consider in detail the change in gross grain harvest for the 1992-2019 period in all states that appeared after the collapse of the USSR (Table 1).

The data in Table 1 allows for the conclusion that in almost all states located in the post-Soviet space, the gross harvest of grain in 2019 increased if compared to 1992. The only exceptions are Kazakhstan, Belarus, Georgia and Armenia. For example, in Tajikistan, grain production during the considered research period increased by 4.91 times, in Uzbekistan - by 2.9 times, in Latvia - by 2.78 times, in Azerbaijan - by 2.58 times, in Lithuania - by 2.36 times, in Turkmenistan - by 2.31 times, in Ukraine - by 2.09 times [7].

Table 1. Change in gross grain harvest in Russia and neighboring countries for the1992-2019 period, million tons

\begin{tabular}{|c|c|c|c|c|c|c|}
\hline \multirow[b]{2}{*}{ Countries } & \multirow[b]{2}{*}{1992} & \multicolumn{3}{|c|}{$\begin{array}{c}\text { Average for the } \\
\text { year }\end{array}$} & \multirow[b]{2}{*}{2019} & \multirow{2}{*}{ 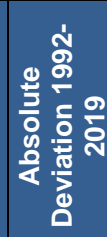 } \\
\hline & & $\begin{array}{l}1992- \\
2000\end{array}$ & $\begin{array}{l}2001- \\
2010\end{array}$ & $\begin{array}{l}2011- \\
2019\end{array}$ & & \\
\hline Russia & 103.79 & 73.29 & 80.39 & 103.69 & 117.87 & 14.07 \\
\hline Ukraine & 35.56 & 30.54 & 38.19 & 61.91 & 74.44 & 38.88 \\
\hline Kazakhstan & 29.65 & 14.75 & 15.76 & \begin{tabular}{|l|}
19.04 \\
\end{tabular} & \begin{tabular}{|l|}
17.36 \\
\end{tabular} & -12.29 \\
\hline Uzbekistan & 2.41 & 3.45 & 6.38 & \begin{tabular}{|l|}
7.38 \\
\end{tabular} & \begin{tabular}{|l|}
6.99 \\
\end{tabular} & 4.58 \\
\hline Belarus & 7.14 & 5.52 & 6.48 & 7.63 & 6.99 & -0.14 \\
\hline Lithuania & 2.21 & 2.44 & 2.81 & 4.77 & 5.21 & 3.00 \\
\hline Moldav & 1.98 & 2.37 & 2.45 & 2.82 & 3.50 & 1.52 \\
\hline Azerbaijan & 1.33 & 1.11 & 2.14 & 2.84 & 3.42 & 2.09 \\
\hline Latvia & 1.14 & 0.96 & 1.27 & 2.37 & 3.16 & 2.02 \\
\hline Kyrgyzstan & 1.60 & 1.42 & 1.62 & 1.64 & 1.82 & 0.23 \\
\hline Turkmenistan & 0.73 & 1.10 & 2.14 & 1.48 & 1.69 & 0.96 \\
\hline Estonia & 0.60 & 0.60 & 0.69 & 1.14 & 1.62 & 1.03 \\
\hline Tajikistan & 0.27 & 0.38 & 0.93 & 1.27 & 1.34 & 1.06 \\
\hline Georgia & 0.50 & 0.57 & 0.53 & 0.39 & 0.37 & -0.12 \\
\hline Armenia & 0.30 & 0.28 & 0.37 & 0.45 & 0.20 & -0.10 \\
\hline $\begin{array}{l}\text { "USSR" as a } \\
\text { whole }\end{array}$ & טינ. & 100.10 & 1001 & 2188 & 245.98 & 56.79 \\
\hline $\begin{array}{l}\text { EAEU as a } \\
\text { whole }\end{array}$ & 142.47 & 95.26 & 104.62 & 132.46 & 144.23 & 1.76 \\
\hline $\begin{array}{l}\text { "USSR" in \% to } \\
\text { the world as a } \\
\text { whole }\end{array}$ & 9.59 & 6.90 & 7.10 & 7.78 & 8.26 & -1.33 \\
\hline $\begin{array}{l}\text { "EAEU" in \% to } \\
\text { the world as a } \\
\text { whole }\end{array}$ & 7.22 & 4.73 & 4.58 & 4.71 & 4.84 & -2.38 \\
\hline
\end{tabular}

Source: Compiled and calculated by the authors based on the FAO data

The EAEU countries show much more modest results, and in some of them this indicator has decreased. For the 1992-2019 period, only Russia and Kyrgyzstan showed the growth of gross grain harvests by $13.56 \%$ and $14.21 \%$, respectively. The decline in production observed in the rest of this integration group is very remarkable from the research point of view; first of all, it concerns reduction of gross harvests in Kazakhstan, since of all the countries located in the post-Soviet space, it occupied and until now occupies the third place in terms of production of cereals [8]. We underline that if in the world as a whole in 2019 the gross grain harvest increased by $50.95 \%$ compared to 1992 , then in the "USSR" group it increased by $30.02 \%$, and in the EAEU group there was only an insignificant increase by $1.24 \%$.

Let us analyze the change in the share of Russia and other states for the 1992-2019 period in the 
EAEU total production volumes (Table 2).

Table 2. Change in the share of Russia and other countries in 1992-2019 in the total volume of gross grain harvest in the EAEU as a whole, \%

\begin{tabular}{|c|c|c|c|c|c|c|}
\hline Countries & 1992 & \begin{tabular}{|c|} 
Aver \\
$1992-$ \\
2000 \\
\end{tabular} & $\begin{array}{l}\text { rage fo } \\
\text { year } \\
2001- \\
2010\end{array}$ & $\begin{array}{l}r \text { the } \\
\begin{array}{l}2011- \\
2019 \\
\end{array}\end{array}$ & 2019 & $\begin{array}{l}\text { Absolute } \\
\text { deviation, } \\
\text { 1992-2019 }\end{array}$ \\
\hline Russia & 72.85 & 76.93 & 76.84 & 78.28 & 81.72 & 8.87 \\
\hline Kazakhstan & 20.81 & 15.49 & 15.06 & 14.38 & 12.03 & -8.78 \\
\hline Belarus & 5.01 & 5.80 & 6.20 & 5.76 & 4.85 & -0.16 \\
\hline Kyrgyzstan & 1.12 & 1.49 & 1.55 & 1.24 & 1.26 & 0.14 \\
\hline Armenia & 0.21 & 0.29 & 0.35 & 0.34 & 0.14 & -0.08 \\
\hline $\begin{array}{l}\text { EAEU as a } \\
\text { whole }\end{array}$ & 100.0 & 100.0 & 100.0 & 100.0 & 100.0 & 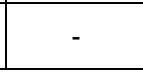 \\
\hline
\end{tabular}

Source: Compiled and calculated by the authors based on the FAO data

It can be concluded that if in 1992, Russia accounted for $72.85 \%$ of volumes from this group, then in 2019 , this value increased by $8.87 \%$, reaching $81.72 \%$. Almost the same in size, but a decrease in the share is typical for Kazakhstan (minus $8.78 \%$ ). Taking into account different trends with changes in the population for the period under consideration in the EAEU countries, we will show the change in gross harvests of this type of product per capita for a more correct comparison of the situation in grain production (Table 3).

Table 3. Change in grain production per capita in the EAEU countries in 1992-2019, kg

\begin{tabular}{|c|c|c|c|c|c|c|}
\hline \multirow[b]{2}{*}{ Countries } & \multicolumn{5}{|c|}{ Average for the year } & \multirow{2}{*}{$\begin{array}{c}\text { Abs. } \\
\text { deviation, } \\
\text { 1992-2019 }\end{array}$} \\
\hline & 1992 & $\begin{array}{l}1992- \\
2000\end{array}$ & $2001-$ & $\begin{array}{l}2011- \\
2019\end{array}$ & 2019 & \\
\hline Russia & 700.0 & 496.1 & 558.2 & 715.6 & 808.0 & 108.0 \\
\hline Kazakhstan & 1818.7 & 945.0 & 1016.3 & 1085.3 & 935.6 & -883.1 \\
\hline Belarus & 702.7 & 550.4 & 677.2 & 809.0 & 739.7 & 37.1 \\
\hline Kyrgyzstan & 358.3 & 305.7 & 315.2 & 275.6 & 284.1 & -74.2 \\
\hline Armenia & 87.1 & 85.9 & 123.9 & 153.2 & 65.9 & -21.2 \\
\hline $\begin{array}{l}\text { EAEU as a } \\
\text { whole }\end{array}$ & 780.2 & 525.6 & 590.4 & 732.8 & 787.1 & 6.9 \\
\hline
\end{tabular}

Source: Compiled and calculated by the authors based on the FAO data

Table 3 presents relative indicators, which, in our opinion, more clearly show not only the production potential, but also the prospects for the consumption of grain products, as well as its possible export without negative consequences for the country's food independence. Currently, it is believed that the minimum per capita grain production rate, excluding livestock production, should be $230 \mathrm{~kg}$ per person. If we add the costs of this type of agricultural raw material for obtaining feed and their subsequent use in cattle, pig and poultry farming and other industries for the production of meat and byproducts, milk and eggs, then the required grain volumes increase by 2.5-3 times, depending on the direction of animal husbandry better developed in a particular country.

\section{DISCUSSION}

In recent years, Russia has become one of the leaders among the countries in the world that specialize in the cultivation of wheat, and has significantly increased the export of grain. As some researchers note, in 2006, 11 million tons of wheat were exported abroad, in 2012 - 22 million tons, in 2015-2016 - 33.9 million tons, in 2016-2017 - 35.5 million tons, in 2017-2018 - 52.4 million tons, while in 1999, the amount of grain export was only 0.8 million tons [9]. The developing countries of Africa and Asia are the main sales market for Russian grain, while Egypt and Turkey are the main importers of Russian wheat [10]. There is no export of this type of product to the developed countries of the world, in particular to the European Union, since for the EAEU countries an individual sub-quota for grain imports, including wheat, is not provided [11].

Nevertheless, from the point of view of the international division of labor, the strengthening of the specialization of Russia, as well as of a number of neighboring countries, in the cultivation of grain and its subsequent delivery to international circulation, is undoubtedly a positive fact [12]. An increase in the production parameters of any product cannot but affect its position in foreign markets if the capacity of the domestic market (consumption) is less than the volume of its production [13]. The grain in this context is an even more remarkable example; in its pricing, the decisive role is assigned to the market environment, both in national markets and in the world. However, not all scientists positively perceive the growth of the gross harvest of cereals in Russia and the increase in the volume of its export to other states [14]. In particular, they argue that the presence of Russia in the world agricultural markets should not create the illusion of well-being in the domestic grain sub-complex. Firstly, the very production of cereal crops in our country is unstable over the years. Secondly, the growth in grain exports became possible mostly due to the reduction in the number of farm animals in Russia, primarily cattle, which led to a drop in demand for concentrated feed from domestic agricultural producers [15].

We share the point of view that the development of exports of agricultural food products in general, and grain in particular, can be considered a macroeconomic indicator of the country's well- 
being only when its volumes increase not as a result of a decrease in the capacity of the domestic market, but due to such an increase in production of a specific type of product that provides both personal and industrial consumption within the state and demand in the external market [16].

One should acknowledge the fact that the present-day Russian grain market, due to objective and subjective reasons, cannot fully cope with significant supply variations on the part of commodity producers.

For example, under favorable natural and climatic conditions, there is a large wheat harvest, which results in an overstocking of markets and a decrease in prices; when a bad year comes, the opposite situation is observed. For the sake of fairness, it should be noted that in any case it is impossible to influence the volume of supply using purely market methods; therefore, it becomes necessary to expand government influence on the relevant processes, including the pricing mechanism.

An increase in grain production in some favorable from the point of view of weather conditions years would not cause sharp fluctuations in prices on the internal market, provided that the process of exporting grain to the countries of near and far abroad is optimized. However, the export of Russian grain has certain specificity, i.e. some countries to which Russia exports its products periodically resort to non-market methods of competition. For example, in case of having their own high harvest, they put up various barriers to access to their market; whereas with a low volume of production, they remove restrictions in order to balance the volume of demand and supply in their domestic market. In terms of risks associated with grain supplies to the countries of near and far abroad, the insufficient development of the transport system in Russia should also be considered, it does not fully satisfy the requests of exporters in the volume and timing of grain delivery [17].

Despite all the negative aspects of the functioning of the grain market mentioned above, this direction remains quite effective and profitable for many Russian agricultural producers and has a positive effect on the development of some rural areas [18]. It should be noted that, in general, favorable for Russia production and market components of the development of the grain industry make it necessary to optimize the grain market and organize supplies within the framework of economic relations between countries located both in the postSoviet space and outside it [19]. When solving this problem, there is a prospect of increasing the volume of grain supplies to some neighboring states, for example, China and Southeast Asia; it can become a significant competitive advantage for Russia not only from an economic, but also from a political point of view [20].

One of the most important factors in increasing the efficiency of the grain economy in Russia is its intensification, the basis of which should be resource-saving and soil-protecting technologies. Their implementation will allow increasing the yield of grain crops, labor productivity, product quality and reducing losses, consumption of fuel, seeds, pesticides, and mineral fertilizers. Reducing the number of technological operations due to the use of latest multifunctional tillage machines will reduce the cost of production [21].

\section{CONCLUSION}

In Russia, as well as in a number of neighboring countries, during the first two decades of the $21 \mathrm{st}$ century, a gradual increase in the gross harvest of cereals was observed; as a result, the grain subcomplex of these countries became export-oriented, especially in regards to wheat [22]. Some researchers underline that the high growth rates of grain exports from our country, especially characteristic of the last ten years, allow assuming that in the coming years Russia will remain one of the leading countries that are the main exporters of this type of product.

However, in terms of the efficiency of grain exports, Russia lags behind the United States and Canada, which is due to the quality of exported products [23].

The export of grain gives Russia certain volumes of export earnings in foreign currency, which is important from the point of view of the stability of the national currency within the framework of the present financial world order [24]

In general, the relationships between the process of cereals production and the products made of them for the saturation of the internal market, as well as for the purpose of their subsequent export, represent a rather deep set of problems. In case of solving these problems, we can speak about the effective interaction between science and practice and between state institutions and those economic entities that are engaged in the growth and export of grain. It implies additional research in the field of the grain sub-complex of both Russia and the EAEU, and other neighboring countries. 


\section{AUTHORS' CONTRIBUTIONS}

The research contribution of each author is as follows: Rafail R. Mukhametzyanov - 0.6, Anastasiya S. Zaretskaya - 0.1, Gulnara K. Dzhancharova - 0.1, Nikolay G. Platonovskiy - 0.1, Natalia V. Arzamastseva - 0.1.

\section{REFERENCES}

[1] N.Y. Kovalenko, "Agricultural economics: textbook for academic bachelor's degree" [Ekonomika sel'skogo hozyajstva: uchebnik dlya akademicheskogo bakalavriata], Moscow, Urait, 2019, 406 p. (In Russ.).

[2] I.A. Boldyreva, O.G. Andryushchenko, A.Y. Nikitaeva, Z.V. Udalova, J. Rudash, "The Agricultural Production and Food Industry Development Trends in the Context of Food Security of Russia”, Journal of Environmental Management and Tourism, 2017, vol. 8(4), pp. 642-647. DOI: 10.14505/jemt.v8.3(19).15

[3] A.S. Zaretskaya, "Statistical evaluation of availability of foodstuff for the region's population within the country's food security", Vestnik NovSU, 2014, vol. 82, pp. 91-95. (In Russ.).

[4] R.R. Mukhametzyanov, A.P. Lesnov, O.N. Mukhametzyanova, "Agricultural markets of the EU and Russia: theoretical and practical aspects (on the example of fruits and vegetables)" [Sel'skokhozyaistvennye rynki ES i Rossii: teoreticheskie i prakticheskie aspekty (na primere plodoovoshchnoi produktsii). Monografiya], M.: Moscow State University of Environmental Engineering, 2005, 243 p. (In Russ.).

[5] R.R. Mukhametzyanov, G.K. Dzhancharova, N.G. Platonovskiy, "Resources and use of fruit and berry products in the main countries of the EAEU", Economics of Agriculture of Russia, 2021, vol. 3, pp. 98-105. (In Russ.). DOI: 10.32651/213-98

[6] Y.I. Agirbov, R.R. Mukhametzyanov, G.K. Dzhancharova, N.G. Platonovskiy, "Changes in potato and vegetable production in Russia and neighboring countries", Economy of agricultural and processing enterprises, 2021, vol. 4, pp. 53-62. (In Russ.). DOI: 10.31442/0235-2494-2021-0-4-53-62

[7] N. Vasylieva, "Ukrainian Cereals in Global Food Security: Production and Export
Components", Montenegrin Journal of Economics, 2020, vol. 16(2), pp. 143-153. DOI: $10.14254 / 1800-5845 / 2020.16-2.11$

[8] V.P. Neganova, Y.F. Chistyakov, "Development of Agricultural Foreign Trade in the Post-Soviet Countries", Economy of Region, 2020, vol. 16(2), pp. 597-611. DOI: $10.17059 / 2020-2-20$

[9] G.Z. Ibiev, "Export and import of grain in the Russian Federation" [Ehksport i import zerna v Rossiiskoi Federatsii], Reports of the TAA: a collection of articles, 2020, pp. 455-459. (In Russ.).

[10]D.A. Zyukin, O.N. Pronskaya, A.A. Golovin, T.V. Belova, "Prospects for Increasing Exports of Russian Wheat to the World Market", Amazonia Investiga, 2020, vol. 9(28), pp. 346355. DOI: $10.34069 / \mathrm{AI} / 2020.28 .04 .39$

[11]E.Y. Frolova, A.A. Nikonov, R.R. Mukhametzyanov, A.F. Korol'kov, A.S. Zaretskaya, "Contradictions to regulatory measures and their impact on global and national agricultural markets", In Proceedings of the International Scientific and Practical Conference «Russia 2020 - a new reality: economy and society», 2021, pp. 276-280. DOI: 10.2991/aebmr.k.210222.054

[12]R.R. Mukhametzyanov, M.N. Besshaposhniy, G.K. Dzhancharova, N.G. Platonovskiy, N.V. Vorontsova, "Dynamics of grain production and export in Russia and neighboring countries", Economy of Agricultural and Processing Enterprises, 2021, vol. 5, pp. 47-58. (In Russ.). DOI: 10.31442/0235-2494-2021-0-5-47-58

[13]D.A. Zyukin, O.N. Pronskaya, O.V. Svyatova, A.A. Golovin, O.V. Pshenichnikova, O.V. Petrushina, "Directions and Prospects for Expanding the Export of Russian Wheat", Revista De La Universidad Del Zulia, 2021, vol. 12(32), pp. 87-101. DOI: 10.46925//rdluz.32.07

[14]E.N. Krylatyh, T.N. Belova, "Russian Grain Exports in the Context of Regional Economic Policy", Economy of Region, 2018, vol. 14(3), pp. 778-790. (In Russ.). DOI: 10.17059/2018-37

[15]B.A. Runov, A.F. Korolkov, V.V. Priemko, "Agrarian policy of the Russian Federation: study guide" [Agrarnaya politika Rossiiskoi Federatsii: Uchebnoe posobie], Moscow, 
RSAU-MAA named after K.A. Timiryazev, 2014, 301 p. (In Russ.).

[16]N.V. Akkanina, M.A. Romanyuk, "Development of Russian exports of agricultural raw materials and food: problems and prospects for domestic and foreign markets" [Razvitie rossiiskogo eksporta sel'skokhozyaistvennogo syr'ya i prodovol'stviya: problemy i perspektivy dlya vnutrennego i vneshnego rynkov], Nikonovsky readings [Nikonovskie chteniya], 2017, vol. 22, pp. 27-32. (In Russ.).

[17]O.V. Berezhnaya, T.G. Martseva, V.I. Berezhnoy, V.N. Glaz, E.V. Berezhnaya, "Modern Aspects of Russia's Foreign Trade Policy and its Export Potential in the Grain Market", Laplage Em Revista, 2021, vol. 7, pp. 434-451. DOI: $\quad 10.24115 /$ S2446622020217Extra-D1124p.434-451

[18] A.L. Popova, A.S. Zaretskaya, K.V. Zhukov, "Spatial Development: Inter-Regional Projects with the Participation of Rural Territories", The European Proceedings of Social \& Behavioural Sciences, 2019, pp. 966-973. DOI: 10.15405/epsbs.2019.12.05.118

[19] S. Onishchenko, "On some Aspects of Food Security of Russia and Belarus", Contemporary Europe-Sovremennaya Evropa, 2019, vol. 1, pp. 119-127. DOI: 10.15211/soveurope12019119127

[20]D.A. Zyukin, D.I. Zhilyakov,
Y.I. Bolokhontseva, O.V. Petrushina, "Export of Russian Grain: Prospects and the Role of the State in its Development", Amazonia Investiga, 2020, vol. 9(28), pp. 320-329. DOI: 10.34069/AI/2020.28.04.36

[21] G.Z. Ibiev, "The efficiency of the grain industry in the region", Agricultural Risk Management, 2016, vol. 2, pp. 23-32. (In Russ.).

[22]M. Svanidze, L. Gotz, "Spatial Market Efficiency of Grain Markets in Russia: Implications of High Trade Costs for Export Potential", Global Food Security-Agriculture Policy Economics and Environment, 2019, vol. 21, pp. 60-68. DOI: 10.1016/j.gfs.2019.07.004

[23]A.G. Ibragimov, G.K. Dzhancharova, V.G. Russkiy, "Grain production in Russia and the world: past and present", Journal of Economy and Entrepreneurship, 2020, vol. 10(123), pp. 1240-1244. (In Russ.). DOI: 10.34925/EIP.2020.123.10.247

[24]R.R. Mukhametzyanov, M.N. Besshaposhny, G.Z. Ibiev, G.K. Dzhancharova, N.G. Platonovsky, "Production and export of grain in the CIS countries" [Proizvodstvo i ehksport zerna v stranakh SNG], in Proceedings of the 72nd ISPC "Advanced technologies in the modern agro-industrial complex of Russia: traditions and innovations", 2021. pp. 288-295. (In Russ.). 